\title{
Sudden quadriparesis in a teenager: a case study and literature review
}

\author{
Niedowład czterokończynowy o nagłym początku u nastolatka: opis przypadku i przegląd \\ piśmiennictwa
}

\author{
Agata Lipiec ${ }^{1}$, Sławomir Barszcz², Monika Bekiesińska-Figatowska ${ }^{3}$ Alicja Goszczańska-Ciuchta1, \\ Elżbieta Szczepanik'
}

${ }^{1}$ Clinic of Neurology of Children and Adolescents, Institute of Mother and Child, Warsaw, Poland

${ }^{2}$ Department of Neurosurgery with Division of Traumatology, Public Paediatric Teaching Hospital, Warsaw, Poland

${ }^{3}$ Department of Diagnostic Imaging, Institute of Mother and Child, Warsaw, Poland

DOI:10.20966/chn.2017.53.412

\section{ABSTRACT}

Introduction: Syndrome of neurapraxia of the cervical spinal cord with transient quadriplegia was first described by Torg et al. in 1986. Cervical cord neurapraxia is defined as a transient neurological deficits following cervical cord trauma.

Aim: In this paper we wanted to share our experience with a rare case of a sudden quadriparesis in paediatric population. Material and methods: The presented case involved a 17-year-old male intensively practicing strength and combat sports who suddenly suffered from quadriparesis with sensory disturbances. Symptoms developed 60 hours after a hyperextension head injury had taken place and subsided completely after 72 hours. Spinal magnetic resonance imaging demonstrated insidious disc changes with congenital cervical spinal stenosis without myelopathy. Disc changes within levels $L 4 / L 5$ and $L 5 / S 1$ with central disc protrusion $L 5 / S 1$ with no central and foraminal stenosis were observed. Differential diagnosis of the case is also presented. Results: Taking into consideration the patient's intense boxing and sparring practice with exposure to head and neck injuries and cervical spinal stenosis, sports-related cervical neurapraxia with transient quadriparesis was diagnosed. Conclusions: Cervical cord neurapraxia is a common consequence of sports-related injury, which should be considered in differential diagnosis, especially in athletes.

Keywords: quadriparesis, cervical spinal stenosis (CSS), cervical cord neurapraxia (CCN), spinal cord injury (SCI), magnetic resonance imaging (MRI).

\section{STRESZCZENIE}

Wprowadzenie. Neurapraksja odcinka szyjnego rdzenia kręgowego z przemijającym porażeniem czterokończynowym została po raz pierwszy opisana przez Torga i in. w 1986 r. Zespół ten jest definiowany jako przemijające deficyty neurologiczne po przebytym urazie rdzenia. Cel: Podzielenie się doświadczeniami dotyczącymi przypadku niedowładu czterokończynowego o nagłym początku, rzadko obserwowanego w populacji dziecięcej. Materiał i metody: Przedstawiono przypadek 17-letniego chłopca intensywnie uprawiającego sporty siłowe i walki, u którego nagle wystąpił niedowład czterokończynowy z zaburzeniami czucia. Objawy rozwinę̨ły się około 60 godzin po urazie przeprostnym glowy i ustąpity całkowicie po około 72 godzinach. Badaniem MR odcinka szyjnego kręgosłupa stwierdzono wąski wrodzony kanat kręgowy z rozpoczynającą się dyskopatią, bez cech mielopatii. Uwidoczniono dyskopatię L4/L5 i L5/S1 z centralną przepukliną dyskową L5/S1, bez istotnej stenozy centralnej i otworowej. Przedstawiono także diagnostykę różnicową przypadku. Wyniki: U pacjenta wzięliśmy pod uwagę intensywne uprawianie boksu i udział w sparingach oraz związaną z tym ekspozycję na urazy głowy i szyi. Kierując się kryteriami diagnostycznymi: związkiem czasowym z urazem oraz wąskim kanałem kręgowym w odcinku szyjnym, u pacjenta rozpoznaliśmy neurapraksję odcinka szyjnego rdzenia kręgowego jako przyczynę przejściowego niedowładu czterokończynowego. Wnioski: Neurapraksja odcinka szyjnego rdzenia kręgowego jest z reguły następstwem urazu związanym z uprawianiem sportów i powinna być brana pod uwage w diagnostyce różnicowej, zwłaszcza u sportowców.

Słowa kluczowe: niedowład czterokończynowy, zwężenie odcinka szyjnego kanału kręgowego, neurapraksja odcinka szyjnego rdzenia kręgowego, uraz rdzenia kręgowego, rezonans magnetyczny.

\section{INTRODUCTION}

Syndrome of neurapraxia of the cervical spinal cord with transient quadriplegia was first described by Torg et al. in 1986 [1].

Cervical cord neurapraxia $(\mathrm{CCN})$ is defined as a transient neurological deficits following cervical cord trauma [1-3]. It is a common consequence of sports-related injury, occurring in 1,3-6 per 10.000 athletes [4], but there have been few studies that thoroughly describe this phenomenon.

\section{CASE STUDY}

History

A 17-year-old male had no reported neurological disorders in the family. The boy was born as a result of normal pregnancy and uneventful delivery.

$\mathrm{He}$ did not report sudden non-consciousness events and demonstrated normal cognitive development with no medical problems until the age of 13 when he discontinued playing football due to the low back pain. Three months 
prior to admission to the hospital the boy had woken up at night, got out of bed and collapsed with no recollection of the event. There were no previous head and spine injuries reported in the patient's medical history. On the other hand, a young boy continued to practice boxing and for the two preceding months participated in sparrings, the most recent one taking place 60 hours before the episode of quadriparesis described below. The boy was working out in the gym (pressing the weight up to 100 kilos), during sit-ups he reported the pain in the neck. Additionally he practiced active running, swimming and playing football.

At the day of admission to the hospital, after nearly 30 minutes of standing during the school assembly, the young patient experienced an acute aggravated pain in lumbar part of the back, shortness of breath, hot flashes, eye scotoma and subsequently, he lost consciousness for a few seconds. He fell down on the floor with no head injuries. After regaining consciousness the patient was quadriparetic - unable to move his legs and with impairment of motion in his arms. A pain in the back persisted with simultaneous headache. The boy was immobilized and transported to our clinic.

\section{Physical examination}

The following examinations were performed: the patient was conscious, fully oriented, respiratory and circulatory efficient, with normal blood pressure and heart rate. Neurological status revealed spastic quadriparesis with present brisk deep tendon reflexes, without pathological signs. The strength in the upper extremities was preserved - motor grade 4 (in Lovett scale), but for lower extremi- ties the grading amounted only to 1 . Hypoesthesia in upper extremities and absence of all sensory modalities below Th12 level was observed in sensory examination, without bladder and rectal disturbances or sphincters dysfunction. Abdominal reflexes were present.

The patient started to regain movement of his lower extremities within 5 hours after the incident and reported pain in lower extremities and spine without radicular signs. The patient demonstrated slow improvement to reach complete neurological recovery within 72 hours.

\section{Imaging}

Magnetic resonance imaging (MRI) of spine and of head was performed. MRI of brain was normal. MRI of cervical spine showed congenital stenosis of spinal canal. Fluid space was visible on levels $\mathrm{C} 2 / \mathrm{C} 3$ and $\mathrm{C} 7 / \mathrm{Th} 1$ with narrowing between them which disappeared at the level of C5/C6. Sagittal diameter equaled $8 \mathrm{~mm}$ at this location. Protruding dises $\mathrm{C} 5 / \mathrm{C} 6$ and $\mathrm{C} 6 / \mathrm{C} 7$ impressed on dural sac (Figure 1). Disc changes within levels L4/L5 and L5/S1 with central disc protrusion on L5/S1 without central and foraminal stenosis were also found. X-ray of the cervical spine was not performed because the neck was not tender, with full motion preserved.

\section{Other tests}

Routine laboratory findings were normal. ECG and Holter ECG revealed no arrhythmias and pauses, echocardiography was without heart abnormalities, USG Doppler of cervical and vertebral arteries without failure.
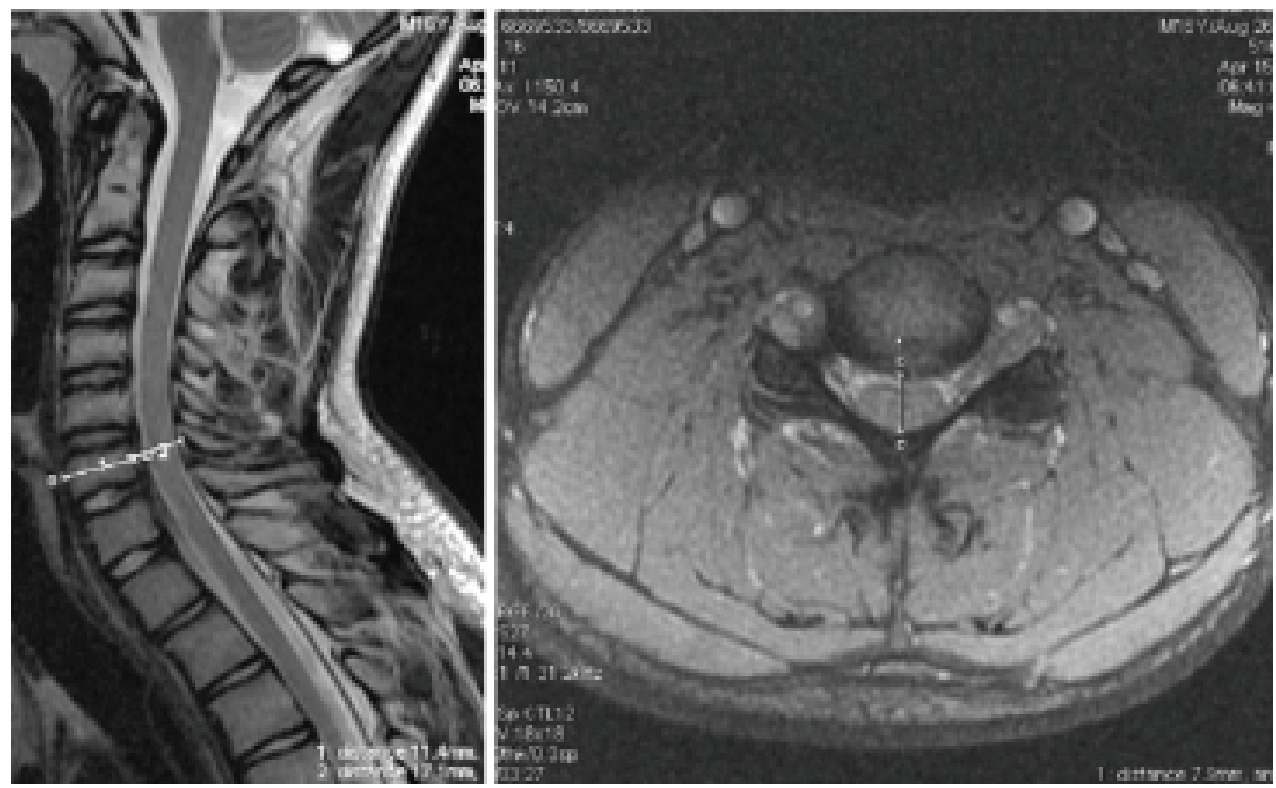

Figure 1. Magnetic resonance imaging of the cervical spine. Congenital stenosis of spinal canal - the sagittal diameter of the canal at the level of C6 is $11 \mathrm{~mm}$ while the same diameter of the C6 vertebral body is $17 \mathrm{~mm}$. The diameter of the canal measured in axial plane at the level of intervertebral disc C5/C6 is $8 \mathrm{~mm}$.

Rycina 1. Rezonans magnetyczny odcinka szyjnego kręgosłupa. Wąski wrodzony kanał kręgowy - wymiar strzałkowy światła kanału na poziomie C6 wynosi $11 \mathrm{~mm}$, ten sam wymiar trzonu kręgu C6 wynosi $17 \mathrm{~mm}$. Średnica kanału mierzona w płaszczyźnie osiowej na poziomie krążka międzykręgowego $\mathrm{C} 5 / \mathrm{C} 6$ wynosi $8 \mathrm{~mm}$. 


\section{Differential diagnosis}

Basing on conducted examinations our patient was diagnosed with a congenital narrow cervical canal. Vertebral fracture, vertebral junction pathology, medullary tumor, acute transverse myelitis, spinal cord infarction, spinal concussion, anterior spinal artery syndrome, thrombotic and embolic disease and medullary arteriovenous malformations were excluded.

Taking into consideration patient's intense boxing and sparring practice with exposure to head and neck injuries and cervical spinal stenosis, sports-related cervical neurapraxia with transient quadriparesis was diagnosed.

\section{TREATMENT}

Nonsteroid anti-inflammatories were used for symptomatic care. After neurosurgical and orthopedical consultations, due to discopathy of L-S spine, physiotherapy (magnetic field and massage) was initiated and was continued for several days during hospitalization. $\mathrm{CCN}$ usually requires only supportive treatment.

With regard to cervical spinal stenosis and discopathy, contact sports, strenuous physical exercises, lifting weights or long-time standing were prohibited. On the other hand, swimming on the back, stationary biking and continued physiotherapy were recommended. Neurosurgical care was recommended as well.

The patient had no neurological deficits on follow-up visits after a few weeks and sixteen months until adulthood. He stopped practicing boxing and playing football.

\section{DISCUSSION}

Cervical cord neurapraxia $(\mathrm{CCN})$ is defined as transient neurological deficits following cervical cord injury. In the episodes a complete recovery usually occurs in 10 to 15 minutes, although in some patients gradual resolution occurs over a period of 36 to 48 hours [1-3]. According to Clark et al. the duration of symptoms was longer in children, a mean duration of 26 hours, with one patient experiencing quadriparesis and paresthesia for 5 days [4]. The sensory changes may be associated with motor changes involving both arms, both legs or all four extremities after forced hyperextension, hyperflexion or axial loading of the cervical spine. Motor changes range from weakness to complete paralysis. The sensory symptoms include burning pain, numbness, tingling or loss of sensation. Except for burning paresthesia, neck pain is not present during injury [1-3].

Hallmarks of the diagnosis of $\mathrm{CCN}$ include the absence of radiographic evidence of spinal cord or osseous injury but demonstrable degree of cervical spinal stenosis or congenital fusion [1-3].

The association of developmental narrowing of the cervical canal with $\mathrm{CCN}$ and transient quadriplegia has been well reported $[1,2]$. Spinal stenosis was determined by canal-vertebral body ratio method devised by Torg and Pavlov [1]. Measurement was made at the level of the third through the sixth vertebral body on a routine lateral roentgenogram of the cervical spine. Using the Torg ratio a cervical segment with one or more vertebra having a canalbody ratio of 0,8 or less indicated significant spinal stenosis as compared to a ratio of approximately 1,00 or more in the control group [1]. The risk of recurrence of spinal cord injury is strongly and inversely correlated with the disclevel canal diameter and the ratio of the spinal canal to the vertebral body [1-3].

In the discussed case the authors did not determine Torg and Pavlov ratio as no X-ray examination of the cervical spine was performed.

Chang, Ellingson et al. [5]. stratified spinal canal stenosis into the following categories:

1. moderate stenosis - trace or no cerebrospinal fluid (CSF) around the spinal cord without the spinal cord deformity;

2. moderately severe stenosis - trace of CSF around the spinal cord with spinal cord deformity;

3. severe stenosis - no CSF around spinal cord with spinal cord deformity. The authors identified a Torg-Pavlov ratio less than 0,7 and spinal canal diameter less than $8 \mathrm{~mm}$ as positive predictors of spinal cord injury. Narrow cervical canal is a suspected risk factor of later development of cervical myelopathy [6].

The observation that $\mathrm{CCN}$ in children may not be associated with cervical spine stenosis is indicative of different mechanism of neurological deficits in this population [4].

The differences in adult and paediatric cervical spine anatomy and traumatic mechanism as well as the differences between cervical spine injury in infants/children and adolescents/teens need to be taken into account. The paediatric cervical spine is more flexible (large head size compared to thin cervical musculature, ligament laxity, incomplete ossification of the vertebral bodies and incomplete development of the spinous processes) and children are at higher risk for injures to the cervical cord [4, 7-9]. Children younger than 8 years are most likely to sustain high cervical injures - the fulcrum for motion in this age group is located at $\mathrm{C} 2 / \mathrm{C} 3$, as opposed to adults, where it is found at $\mathrm{C} 5 / \mathrm{C} 6$. Children over the age of 12 years have anatomy similar to adults, resulting in similar injury patterns $[4,8$, 9]. The age of a child helps predict the type of injury and, therefore, can help to guide imaging decisions [8].

Spinal cord injury without radiographic abnormality (SCIWORA) occurs almost exclusively in young children because of their unique biomechanics, described above [9]. SCIWORA represents a mean incidence of traumatic paediatric spine injury that results in sensory and/or motor deficits $[4,7,9,10]$. Spinal cord ischaemia is one of proposed mechanisms of SCIWORA [10]. Ninety percent of SCIWORA cases occur in paediatric populations at average age of 7-8 years. The most common mechanisms resulting in SCIWORA are motor vehicle crashes, falls and sports accidents. Three-fourth of SCIWORA injuries occur in the cervical spine. Children can often demonstrate delayed symptoms up to 4 days after the initial injury [9]. The most common clinical presentations are partial cord syndrome, complete cord syndrome, central cord syndrome, Brown-Sequard syndrome and anterior cord syndrome $[9,11]$. CCN in children can be considered as a mild form of SCIWORA in which the forces that deform the spine are sufficient to cause reversible per- 
turbation of spinal cord physiology without permanently damaging the cord [4].

The "burner" or "stinger" results from either of two injury patterns: traction to the brachial plexus or compression of the cervical nerves roots. Brachial plexus injures are typically traction neurapraxias occurring in younger athletes as a result of shoulder depression and lateral neck flexion away from the side of injury. This injury results in unilateral, transient burning sensation and radiating pain from the shoulder down to the hand, it is often difficult to distinguish from a spinal cord injury. Typically the symptoms only last from 30 seconds to several minutes, but they can last up to several days $[3,7,11]$.

Mechanism of neurapraxia represents a reversible aberration of axonal function, with temporary derangement of axon permeability. It is a histochemical response of squid axon injury that results in prolonged refractory period in conduction [3, 4, 11, 12]. Data obtained by Torg et al. [12]. indicate that recovery or lack thereof is directly proportional to the intracellular calcium concentration in the axon. The proportion of intracellular calcium was in turn directly proportional to the amount of tension applied to the axon. It is concluded that disruption of cord function is a result of the effects of local cord anoxia and increased concentration of intracellular calcium. A blood flow restoration and reduction of intracellular calcium level will increase neurologic recovery [12].

More recently the role of methylprednisolone in patient with acute spine injury has been questioned [13]. According to the literature, steroid treatment needs to be considered on case-to-case basis, and due to progressive recovery as observed in our patient we did not decide to use steroids.

\section{CONCLUSIONS}

In this paper we wanted to share our experience with a rare case of sudden quadriparesis in paediatric population. $\mathrm{CCN}$ is a common consequence of sports-related injury, which should be considered in differential diagnosis. Neurological symptoms usually last less than 15 minutes, but can persist up to 48 hours in adults and as long as 5 days in children. $\mathrm{CCN}$ is associated with cervical spinal stenosis in adult athletes, however not in the paediatric population due to mechanism of injury formation as explained earlier in the paper. Determination of Torg ratio in patients after $\mathrm{CCN}$ is recommended in order to exclude spinal stenosis. Therefore, after $\mathrm{CCN}$ episodes, the risk of returning to sports should be assessed individually for each patient.

Absolute contraindications to returning to athletic activity after documented episode of $\mathrm{CCN}$ are ligamentous instability, a single neurapraxic event with evidence of cord damage, multiple events, and/or events with symptoms lasting longer than 36 hours $[3,9]$.

\section{ACKNOWLEDGMENTS}

Financial support: none

\section{CONFLICT OF INTEREST}

On behalf of all authors, the corresponding author states that there is no conflict of interest.

\section{REFERENCES}

[1] Torg J.S., Pavlov H., Genuario S.E., et al.: Neurapraxia of the cervical spinal cord with transient quadriplegia. The Journal of Bone and Joint Surgery 1986; 68 (9): 1354-1370.

[2] Torg J.S., Corcoran T.A., Thibault L.E., et al.: Cervical cord neurapraxia: classification, pathomechanics, morbidity, and management guidelines. Journal of Neurosurgery 1997; 87(6): 843-850.

[3] Torg J.S.: Cervical spine injuries and the return to football. Sports Health 2009; 1(5): 376-383.

[4] Clark A.J., Auguste K.I., Sun P.P.: Cervical spinal stenosis and sportsrelated cervical cord neurapraxia. Neurosurgery Focus 2011; 31(5): 1-4.

[5] Chang V., Ellingson B.M., Salamon N., et al.: The risk of acute spinal cord injury after minor trauma in patients with preexisting cervical stenosis. Neurosurgery 2015; 77(4): 561-565.

[6] Nakashima H., Yukawa Y., Suda K., et al.: Narrow cervical canal in 1211 asymptomatic health subjects: the relationship with spinal cord compression on MRI. European Spine Journal 2016; 25(7): 2149-2154.

[7] Rich V., McCaslin E.: Central cord syndrome in a high school wrestler: A Case Report. Journal of Athletic Training 2006; 41(3): 341-344.

[8] Easter J.S., Berkin R., Rosen C.L., et al.: Cervical spine injuries in children, part I: mechanism of injury, clinical presentation, and imaging. The Journal of Emergency Medicine 2011; 41(2): 142-150.

[9] Kreykes N.S., Letton R.W. Jr,: Current issues in the diagnosis of pediatric cervical spine injury. Seminars in Pediatric Surgery 2010; 19: 257-264.

[10] Nance J.R., Golomb M.R.: Ischemic spinal cord infarction in children without vertebral fracture Pediatric Neurology 2007; 36(4): 209-216.

[11] Zahir U., Ludwig S.C.: Sports-related cervical spine injuries: on-field assessment and management. Seminars in Spine Surgery 2010: 173-180.

[12] Torg J.S., Thibault L., Sennett B., et al.: The Nicolas Andry Award. The pathomechanics and pathophysiology of cervical spinal cord injury. Clinical Orthopaedics and Related Research 1995; (321): 259-269.

[13] Taneja A., Berry C.A., Rao R.D.: Initial management of the patient with cervical spine injury. Seminars in Spine Surgery 2013; 25: 2-13.

\section{Correspondence:}

Agata Lipiec, MD, Clinic of Neurology of Children and Adolescents, Institute of Mother and Child, Kasprzaka 17A, 01-211 Warsaw, Poland

e-mail: agata_lipiec@op.pl 